\title{
Linking teaching and research in initial teacher education: knowledge mobilisation and research-informed practice
}

\author{
Maria Assunção Flores (D) \\ Research Centre on Child Studies, Institute of Education, University of Minho, Braga, Portugal
}

\begin{abstract}
The link between theory, practice and research in Initial Teacher Education (ITE) has been widely discussed in international literature. However, more needs to be done in regard to the examination of concrete examples to foster research and teaching practice in existing teacher education programmes. This paper focuses on a practicum model in ITE which aims at linking teaching and research, theory and practice. The reflective component of the model is oriented towards student teacher professional development under a democratic view of education. Integrating teaching and research and promoting teaching practice as a space of transformation rather than a process of adaptation or of application of theory may well represent a move towards knowledge mobilisation and researchinformed practice. The paper concludes with some lessons learned and possible directions in order to overcome the shortcomings of the model and to enhance its positive and innovative features.
\end{abstract}

Abbreviation ITE: Initial teacher education

\section{KEYWORDS}

Knowledge mobilisation; practicum; research-informed practice; teacher education

\section{Introduction}

The link between theory, practice and research in Initial Teacher Education (ITE) has been widely discussed in international literature (e.g. Van Nuland 2011; Flores 2017; Valeeva and Gafurov 2017; Marcondes, Leite, and Ramos 2017). However, more needs to be done to foster these components in existing teacher education programmes. In general, there has been a growing recognition of the importance of the use of research to inform practice and to enhance teacher professionalism. In this context, the need to foster and sustain knowledge mobilisation and generation has been advocated through, for instance, developing an inquiry approach in initial teacher education (ITE) and to integrate research into practicum (e.g. Qvortrup 2016; Flores et al. 2016).

The importance for all teachers to become research literate and to provide them with opportunities for engagement in research and inquiry has been advocated (BERA-RSA, 2014). The same report emphasises that schools and colleges are to be seen as researchrich environments and that 'teacher researchers and the wider research community work in partnership, rather than in separate and sometimes competing universes' (5). 
However, the use of research in teaching and in teacher education is controversial as well as the concepts that revolve around this topic. Terms such as knowledge mobilisation, knowledge generation, knowledge mediation, knowledge transfer, knowledge exchange, knowledge acquisition, knowledge utilisation, knowledge translation, and knowledge transformation are but a few examples that can be found in recent literature, in education and in other fields, the discussion of which is beyond the scope of this paper (see, for instance, Weiss 1979; Van Der Walt 2006; Levin 2013; Braedley 2016; Matheson and Edwards 2016). In this article, I look at the link between teaching and research by focusing on the practicum model for initial teacher education that is in place in my institution. I particularly address the notions of research-informed practice and knowledge mobilisation by describing the key dimensions of the model as well as current challenges and possibilities.

In general, the gap between research, practice and policy, or at least, the weak links between them are recurrently pointed out in the literature, mainly associated with the hiatus between knowledge producers (academic researchers) and knowledge users (teachers) (Dimmock 2016), and between (teacher) education as reproduction and transformation (Vieira 2016, 2017).

Cain, Wieser, and Livingston (2016) draw a distinction between knowledge mobilisation and research-informed practice. The former is the process by which knowledge is transferred from a research community to other communities, i.e. policy and practice communities. They also define research use as the 'ways in which research is interpreted and used by policy makers and practitioners' and they state that 'when researchgenerated knowledge is used by practitioners, we can refer to this as research-informed practice' (529, original emphasis).

Knowledge mobilisation

needs to attend to the capacity to access, understand, share and act on many forms of evidence, including research (Nelson and Campbell 2017, 130).

In a similar vein, Levin $(2013,2)$ defines knowledge mobilisation based on the

efforts to understand and strengthen the relationship between research and practice". His understanding of the concept reinforces the "interactive, social and gradual nature of the connection between research and practice" which goes beyond a "one-way process" (2).

However, as Cain (2016) suggests, teachers look at research in different ways not only in terms of attitudes but also in terms of the practical uses of it. Teacher inquiry and action research have been widely discussed in international literature (e.g. Sachs, 2009). However, in recent years, the importance of a research-based teaching profession and the need to make stronger connections between research and practice have expanded considerably (e.g. Cain, 2015a; Jones, Procter, and Younie 2015; Dimmock 2016; lon and lucu 2016; Rey and Gaussel 2016; Qvortrup 2016; Ostinelli 2016; Cooper, Klinger, and McAdie 2017; Nelson and Campbell 2017).

The different studies show some positive elements but also some issues that deserve further consideration in order to enhance teaching as a research-informed profession. For instance, lon and lucu (2016) found that postgraduate studies provide teachers with an opportunity to link research conducted by faculties of education and their own work in schools. The same study suggests the need to develop research projects involving 
both researchers and teachers as well as reading about research as examples of strategies that might facilitate research utilisation in practice. In a study of how secondary school teachers used research findings about gifted and talented students through action research projects devised by themselves, Cain (2015a) concluded that teachers were able to transform propositional knowledge into practical knowledge by developing their conceptual understandings. He also found that teachers transformed abstract, impersonal knowledge into context-specific, personal knowledge, and that they transformed narrowly focused knowledge into broadly focused knowledge. The same author argues for the need to examine further how teachers use research texts, why they choose given texts or why they reject or ignore research (Cain 2015b).

Also, more recently, in discussing and conceptualising the problems and possibilities of knowledge mobilisation and professional development in schools, Dimmock (2016) identified three main issues:

(i) bridging the research-policy-practice gap by mobilising knowledge more effectively through knowledge producers and consumers working collaboratively;

(ii) valuing and integrating both tacit knowledge and academic coded knowledge; and

(iii) raising the professionalism and reflexivity of teachers and leaders.

The same author argues for the need to develop 'research-engaged' schools which, amongst other features, are seen as sites for research design, methodology and application and in which intervention projects tackling practical problems and joint research programmes between schools and universities are developed (Dimmock 2016). In a similar vein, Rey and Gaussel $(2016,577)$ advocate that 'research knowledge in education should be considered by teachers and school leaders prior to being disseminated, in order to be shaped according to the complexity of educational practice'.

In addition, Darling-Hammond (2017), drawing on well-developed systems for teacher education around the world, identifies a set of leading practices that might be considered as 'promising strategies' for improving teaching and teacher learning. Amongst other issues, she stresses the need to connect theory and practice through the design of thoughtful coursework and the integration of high-quality clinical work in contexts in which good practice is nurtured. In the following sections, I look at the ways in which the model of practicum currently in place in my institution links research and teaching by drawing upon earlier work. I revisit the model and conclude with some lessons learned and possible directions in order to overcome the shortcomings of the model and to enhance its positive and innovative features.

\section{Changing initial teacher education (ITE): the post-Bologna context}

In this section I briefly describe the context of teacher education in Portugal. As a result of the implementation of the Bologna Declaration (1999), teacher education programmes were restructured. 


\section{A consecutive model}

Since 2007, the qualification for teaching is to be obtained in a two-year master programme in teaching, after a three-year undergraduate degree in a given subject (Decree-Law No. 43/2007) for all sectors of teaching (from pre-school to secondary school; in the case of pre and primary school, student teaches do a first degree in Basic Education and then a Master's degree in Teaching). In other words, a consecutive model was introduced replacing the 4 to 5 year undergraduate teaching degrees which were of two types:

(i) five-year integrated programmes which included 4 years of full-time study at university in which student teachers would benefit from education in educational sciences and subject matter simultaneously from the very beginning of the programme plus one year of practicum in a school;

(ii) sequential programmes where students did their education to become teachers for one or two years, after completing three years of subject-related education.

The post-Bologna context implied, therefore, a new configuration for all initial teacher education programmes within the context of a higher qualification for teaching (Master's level) which presented both new and old challenges and problems, namely the link between theory and practice and the fragmentation of the curriculum components of ITE (see, Flores 2011; Flores, Vieira, and Ferreira 2014; Flores et al. 2016; Vieira et al. forthcoming).

\section{The valorisation of the professional practice}

The legal framework currently in place stipulates five curricular components: subject knowledge, general education, specific didactics, initiation to professional practice, and ethical, social and cultural education (Decree-Law No. 79/2014). In general, there is an emphasis on subject knowledge, on didactics and on the professional practice even though, paradoxically, student teachers spend less time in schools within the context of a 2-year Master's degree in Teaching. This is due to the fact that this new configuration resulted in a reduced time and space for practicum (which occurs only at master's level), with implications for the pedagogical activities that student teachers are able to develop. As Moreira and Vieira (2012,) stated,

the impact of this structural change is not yet clear; will second-cycle student teachers take teaching more seriously because they had more time to decide to become teachers, or will they take it less seriously because their training is shorter? And will they be able to integrate subject and pedagogical knowledge now that these curricular components are clearly separated? ( $p$ 97).

Research findings related to ITE in the post-Bologna context in Portugal suggest the importance of the practicum as a key component of the curriculum of ITE for developing professional knowledge and competencies. However, critical issues were also identified, such as the length of practicum, the quality of supervision, the support received and the articulation amongst the different components of the curriculum (Flores 2014). Studies focusing on the new model at my institution point out positive outcomes of the model as well as problems related to a poor articulation between practicum seminars and 
pedagogical practice, lack of time and conditions for project design and development, and also tensions regarding the teaching-research nexus (Flores et al. 2016; Vieira 2014; Vieira et al. 2013, forthcoming). This is particularly challenging within the context of a research-oriented practicum design to which I now turn.

\section{A research-oriented approach to the practicum}

The new configuration of ITE at Master's level implied a research component that was tacitly assumed by institutions and encouraged by external assessments (Vieira et al. forthcoming). This research dimension was identified explicitly as a compulsory component of the ITE curriculum in the first legal framework (see Decree-Law No. 43/2007), but with no credits allocated for it. It aimed at 'enabling prospective teachers to adopt a research stance in their professional performance in specific contexts, on the basis of an understanding and critical analysis of relevant educational research' (Decree-Law No. 43/2007). Even though in the new legal framework issued in 2014 (Decree-Law No. 79/2014) the research component no longer figures as a compulsory component of the curriculum of ITE, it has been assumed as a key element in the practicum experience during ITE in most institutions, albeit in diverse formats. In the next section, I describe the key elements of the practicum model in my institution by arguing for the relevance of research-informed practice and knowledge mobilisation in student teachers' professional development.

\section{Knowledge mobilisation and research-informed practice in ITE}

ITE programmes in Europe and elsewhere vary when it comes to the research component. As Flores (2016) asserts, in some programmes it is non-existent, in other cases it is not explicit in the curriculum and it is up to the training institutions to include it or not, for instance during practicum. However, in other cases there is an explicit curriculum unit on research methods in ITE as well as an inquiry approach to the practicum. There are, therefore, variations across programmes 'from one compulsory methods course to a critical reading of research papers and use of databases for policymaking recommendations' (Niemi and Nevgi 2014, 132) to the development of a pedagogical intervention project with a research component (action research) during the practicum in a school (Flores, Vieira, and Ferreira 2014).

In some ITE programmes around the world, it is possible to identify a research orientation visible in courses and modules as well as in the involvement of student teachers in research projects (see Flores 2016, 2017). For instance, the introduction of research into the curriculum in France has been seen as a strong feature (Lapostolle and Chevaillier 2011). In the Netherlands, Snoek et al. (2017), based on empirical evidence, analyse the involvement of student teachers in research projects and on the contribution of these research projects to their reflective and inquiring competences. They argue for the need to develop research projects in order to go beyond the individual and personal level aiming at contributing to research informed reflection of a team of teachers, creating input for the improvement of practice within the whole school. They further state that connecting graduation research projects with school development is more than a matter of redesigning of the ITE curriculum. It entails new 
perspectives and new qualities on the part of student teachers, research supervisors from the university and of actors within the school.

Additionally, in Brazil, in order to foster the development of partnerships between schools and universities and to enhance the research dimension of teacher education, the PIBID (Programa Institucional de Bolsa de Iniciação à Docência - Institutional Programme for grants to initiate teaching) was launched in 2007. The principles underpinning the PIBID included:

(i) basing teacher education on teachers' work at school and on real experiences;

(ii) combining theoretical and methodological teacher knowledge of higher education institutions and the practical and experiential knowledge of teachers in schools;

(iii) paying attention to the multiple dimensions of the daily work of school and to research aimed at solving practical situations and innovations in education and,

(iv) promoting dialogue and collaborative work by fostering the social nature of the teaching profession (Brazil, 2012).

The most paradigmatic example, however, of research in ITE coming to prominence in the international literature is the Finnish research-based model of teacher education (Flores 2014). Hökkä and Eteläpelto (2014) highlighted the strong focus on a 'researchbased curriculum' in ITE in Finland which includes the study of research methods and the writing of a master's thesis aiming at training 'autonomous and reflective teachers capable of adopting a research-oriented attitude toward their work' (42).

In the Finnish ITE curriculum, research studies encompass the 'theoretical basis for research work (e.g. reading and reviewing research literature and learning research methods) and conducting authentic research projects' (Niemi and Nevgi 2014).

Similarly, the research (action-research) component in the practicum has been seen as a positive aspect of the master's degrees in teaching in Portugal (Flores 2014; Flores, Vieira, and Ferreira 2014). Drawing on a study of the syllabi of current programmes, Vieira et al. (forthcoming) concluded that the major innovation regarding practicerelated learning was the new practicum model, based on a transformative view of teacher development and on an inquiry-based approach to teaching. During the practicum student teachers are expected to do lesson observation and context analysis as a basis for designing and conducting a pedagogical project in school.

\section{The rationale: a transformative view of education and research-informed practice}

One of the major challenges within the new legal framework for ITE was to 'design a model for the practicum within a tradition of practicum without any model' (Vieira et al. 2013, 2642), namely in regard to the lack of definition of the role of supervisors, the nature and goals of practicum strategies in terms of training and supervision, as far as observation was concerned, lack of connection between theory and practice and between research, training and teaching, lack of stability of university-school partnerships and lack of dialogue and inability to promote educational change, (Flores, Vieira, and Ferreira 2014). 
A look at the internal documents regulating the practicum in my institution reveals that its aims are:

(i) to promote a critical understanding and intervention in pedagogical contexts;

(ii) to deepen the development of subject matter and pedagogical competencies;

(iii) to develop a research culture and collaboration in professional training and,

(iv) to develop the integration of cultural, social and ethical aspects in professional training.

In addition, three main dimensions associated with the professional profile of student teachers (see Figure 1) are identified:

(i) the conceptual dimension (which relates to the theoretical framework of professional practice);

(ii) the strategic dimension (associated with the methodological framework of professional practice) and,

(iii) the axiological dimension (which deals with the values of professional practice).

This framework for the practicum was in place for the first time in $2008 / 2009$. The main underpinning principles and assumptions draw on the complex and ideological nature of the teaching experience as a transforming and challenging praxis (Vieira et al. 2013; Flores, Vieira, and Ferreira 2014). Thus, the model for practicum was to be seen as a space for articulating teaching and research based on a transformational and emancipatory view of professional practice in line with the creation of a 'third space' (Zeichner

\section{Conceptual dimension}

- Related to the theoretical framework of professional practice

- Subject knowledge, didactics, general educational knowledge, research and context.

\section{Strategic dimension}

- Associated with the methodological framework of professional practice - Processes and techniques of analysis and development of subject knowledge and of teaching and learning, regulation of and research into teaching, and understanding and transformation of intervention contexts.

\section{Axiological dimension}

- Linked to values of professional practice

- Ethical and political values that underpin educational action with its ethical and political implications.

Figure 1. The three dimensions of professional practice (adapted from internal document regulating the practicum at the University of Minho, Portugal). 
2010) where professional and academic rationales are combined to generate relevant educational knowledge through dialogue and inquiry.

\section{The pedagogical project}

Student teachers are expected to conduct a small-scale pedagogical project which aims at combining teaching and research under the supervision of university supervisors and the co-operating teachers at school. The themes vary according to context analysis and student teachers' interests and motivations. Student teachers attend seminars and modules at the university that are intended to support the development of the pedagogical project in light of their needs and interests (e.g. classroom management, inclusion and special needs, cognitive processes and learning, lesson observation and pedagogical inquiry). The assessment of the practicum results from the work developed both at university and at school/in the classroom, and in particular from the development of the pedagogical project. It includes participation of the student teachers in seminars and supervision conferences (university and school), in classroom observation and in developing a portfolio which documents their learning throughout the practicum, especially with the implementation and evaluation of the pedagogical project. The portfolio serves as a basis for the final report on the practicum project, which is 25.000 30.000 words in length, and is seen as a professional narrative of student teachers' learning experiences during practicum.

The design and development of the pedagogical project draws upon a set of principles that include a humanistic and democratic view of schooling, the adequacy of interventions to the contexts of practice and their educational value in regard to teacher and learner experience, the use of data collection to support the understanding and renewal of pedagogy, and the enhancement of professional development based on reflectivity, self-direction, collaboration, creativity, and innovation. Assessment of the practicum takes into account student teachers' work in seminars, supervision conferences and project development (50\%), as well as the final report (50\%). At the end student teachers need to pass a public viva voce examination led by an examining board composed of the programme director, the university supervisor and one or two teacher educators from within the institution or from other institutions.

The final report presents and discusses the development of the pedagogical project based on data collected during practicum. Flores et al. (2016) study, based on data collected through a survey questionnaire and focus group interviews to practicum participants, as well as on the analysis of a corpus of student teachers' practicum reports, shows that the emergence of an inquiry-based culture in the practicum was both innovative and controversial, including tensions and challenges in regard to visions of teacher education, as well as (mis)matches between curriculum rhetoric and implementation. The authors point to the need to develop a scholarship of teacher education whereby ITE programmes are investigated and improved on the basis of negotiated understandings, particularly in regard to research and teaching nexus. 


\section{Cultivating a research culture}

One of the aims of the practicum is to foster a research dimension in student teachers' experience at school in order better to inform their pedagogical practice. As Vieira (2016) asserts, pedagogical inquiry is both necessary and controversial, in so far as it teaches something valuable about the possibility of building a more democratic education in schools. Flores et al. (2016), drawing upon a study of research reports of practicum (see also Vieira et al. 2013), found that it was possible to identify three kinds of research designs. Two of them mirror the two different teacher education rationales identified by Zeichner and Conklin (2008):

(i) implementing a particular teaching approach documented in the specialised literature and assessing its effectiveness through pre-/post-tests, whereby student teachers more or less 'faithfully follow teaching scripts based on methods that allegedly have been shown to promote student learning' (273);

(ii) implementing action research or interventions including the evaluation of their impact, aimed at 'developing teachers' abilities to make decisions about which methods to use with particular decisions at a particular time' (273).

A third orientation towards research was also identified that

resembles action research, but information collected during teaching does not feed into practice, and therefore its connection to teacher decision-making and pedagogical improvement is not clear (Flores et al. 2016, 120).

Earlier studies point to the relevance of research in developing pedagogical practice focused on the quality of teaching and learning (Flores et al. 2016; Vieira 2014; Vieira et al. 2013, forthcoming). However, they also suggest the co-existence of different modes of articulating research and teaching that are associated with diverse views of teacher education and the role of research in practice and in the (re)construction of professional competences. As the main positive issues, the studies identify the exploration of diverse approaches framed in current views of education within a democratic perspective, being change-oriented; the mobilisation of different kinds of knowledge; the articulation of pedagogical and research purposes in practicum; and the diversity of data collection methods and assessment modes designed to better understand student and teacher development.

Research drawing on the analysis of practicum reports in my institution has shown the opportunity for student teachers to mobilise and develop various kinds of knowledge related to different aspects of the development of the pedagogical project, namely contextual, educational, content-related and research-related knowledge (Flores et al. 2016). The authors analysed 32 reports completed between 2011 and 2013 within 7 ITE programmes (Biology-Geology, Mathematics, Philosophy, Portuguese-Spanish, English-Spanish, Primary Education, Pre-school Education). The goal of the study was to understand the nature of practicum projects and the role of research in professional development and pedagogical renewal. Findings showed that both contextual and educational knowledge are more explicitly present in the practicum reports followed by content-related knowledge. In other words, student teachers 
were able to mobilise various kinds of knowledge by expanding 'the enactment of a praxeological epistemology' (Vieira et al. forthcoming).

They are able to mobilise knowledge to characterise teaching contexts, to identify problems or concerns and to justify the focus of research. In addition, they can describe and justify pedagogical and research strategies and examine their practice.

In general, practicum reports illustrate the ways in which research is used to understand and transform education. Student teachers are able to develop reflective practice. Research is seen as the central element in the (re)construction of the thinking and practice of teachers-to-be. However, knowledge about research is the least present kind of knowledge in the practicum reports. In other words, even though student teachers are able to design, develop, describe and interpret pedagogical inquiry, they do not use theoretical research knowledge very often when they need to justify research options and analyse research processes (Flores et al. 2016). To put it differently, they need more declarative knowledge about research. In order to overcome this, a new practicum seminar (30h) run by programme coordinators was created to support project design and provide more explicit training in pedagogical inquiry.

Further improvements are needed in terms of making more explicit the ethical and conceptual framework underpinning the pedagogical projects, mobilising knowledge about research in justifying the methodological options and data analysis, integrating theory and practice in data analysis, and reflecting about the limitations and recommendations for training, supervision and research on teaching (Flores et al. 2016; Vieira et al. forthcoming).

Overall, one might say that the new practicum model is one of the most innovative features of ITE in the post-Bologna context in my institution. It enables student teachers not only to mobilise different kinds of knowledge and to inform their pedagogical choices and decisions but also to foster the capacity to generate new knowledge. They are provided with opportunities to identify a specific problem in a given context as a starting point to develop their pedagogical project in which the research dimension is key. Because this model challenges previous conceptions and practices in teacher education, it raises issues and tensions whose resolution strongly depends teacher educators' ongoing commitment to investigating and improving it.

\section{Discussion}

This paper set out to present a brief account of the practicum model in ITE in my institution. It draws upon a transformative view of education, knowledge mobilisation and a research-informed pedagogical practice. The model was considered to be one of the most innovative but at the same time controversial features (see Flores et al. 2016; Vieira et al. forthcoming) of the ITE programme in the post-Bologna context. Integrating research into teaching is a key strategy to prepare reflective practitioners, and to enhance the transformative potential of a practicum experience (Vieira et al. forthcoming).

The importance of research within the context of ITE in fostering a more consistent and deeper approach to teaching has been advocated in many contexts. The BERA-RSA report (2014) identified different ways in which research can make a contribution to teacher education, amongst which are: 
research can be used to inform the design and structure of teacher education programmes, teachers and teacher educators can be equipped to engage with and be discerning consumers of research, and teachers and teacher educators may be equipped to conduct their own research, individually and collectively, to investigate the impact of particular interventions or to explore the positive and negative effects of educational practice (p 5).

Recent empirical work shows that Finnish student teachers value research experiences that promote the development of professional competences and support their growth toward evidence-based practice and $21^{\text {st }}$ century skills (Niemi and Nevgi 2014), which corroborates earlier research (Jyrhama et al. 2008). Active learning experiences in ITE reinforce the view that conducting research studies has a positive effect on professional competences in that 'student teachers' professional competences were much higher when both research studies and active learning experiences supported them' (Niemi and Nevgi 2014, 140).

In addition, a report on teacher education in nine countries (Ireland, Northern Ireland, Scotland, England, Finland, USA, Poland, Singapore and New Zealand) stressed the need to promote reflection and inquiry to enhance knowledge integration (Conway et al. 2009). The findings suggest that in order to promote greater coherence and knowledge integration in ITE curriculum, reflective practice has been complemented by a growing emphasis on the inquiry/research dimension.

\section{Lessons learned and possible directions}

The studies identified above (e.g. Vieira et al. 2013; Flores et al. 2016) pointed to the development of a research-informed pedagogical practice enhanced by opportunities to mobilise different kinds of knowledge. Earlier empirical evidence has also shown the potential of the model of practicum in fostering a research culture within ITE but also in developing a critical and inquiry attitude from the part of the student teachers.

Nevertheless, there is room for improvement. Further developments are needed to improve the research dimension within the ITE curriculum in a more explicit and articulated way, namely in regard to the understanding of professional development underpinning student teachers' pedagogical projects and learning experiences as well as the training of student teachers in research methods. Recent changes in the ITE curriculum described in this paper aimed at overcoming this challenge. A new practicum seminar (30h) was created to support project design and provide more explicit training in pedagogical inquiry. However, more attention needs to be given to the research dimension from the very beginning of the programme in a more articulated and consistent way. In other words, student teachers should be introduced to research earlier on by reading and examining research findings in their field, by engaging in existing research projects, mainly those which involve university-schools' partnerships. Recently, Afdal and Spernes (2018) found that academic reading systematically enabled student teachers to integrate research-based knowledge with professional practice in various ways.

Another issue that needs to be enhanced is associated with the expansion and effects of the pedagogical projects not only on student teachers' pedagogical practice and professional development, but also on the schools in which they work. This is in line 
with earlier research (Snoek et al. 2017) which suggests that connecting graduation research projects with school development requires new perspectives and new qualities of student-teachers, research supervisors from the university and actors within the school.

Similarly, in the context of academic and university-based ITE in Finland, Hökkä and Eteläpelto (2014) identified three major challenges:

(i) obstacles in renegotiating professional identity;

(ii) internal competition between subject-matter groups within the department and

(iii) discrepancies between individual agency and organisational development

The authors argued that teacher educators' individual and collective agency needs to be supported to enhance their continuous professional learning and organisational change.

In the Portuguese context, Flores et al. (2016) stressed that the integration of research into the practicum faced a number of challenges. These are related to time and resources as

condensing professional development in two-year master programmes led to a reduction of time allocated to school-based practice, with potential negative effects upon students' preparation and opportunity to engage in pedagogical inquiry ( $p$ 112).

The same authors also identify the risk of making the practicum 'more academic and less profession-oriented' and with both supervisors and cooperating teachers who need to reshape their traditional roles and 'to expand professional competences in order to become partners of pedagogical inquiry and renewal'. The development of educational reforms which are rather 'outcomes-based ideology' undervaluing 'the moral and political dimensions of teaching' may lead to 'managerial school cultures' which in turn 'may reduce the transformative potential of inquiry-based practice (see Dover, 2013; Pillen et al., 2013; Moreira and Vieira 2012)'. Finally, Flores et al. (2016) suggest that the lack of scholarship of teacher education, 'whereby teacher educators work in communities of practice to study and improve their practices, may disempower them as agents of change in academic settings where teacher education still tends to rely on a positivistic epistemology and on technical rationality rather than on a socio-constructivist view (Kinchleoe, 2003).'

One of the main challenges in implementing a new model for teacher education relates to the co-existence of different conceptions on the part of teacher educators, namely in regard to the role of research in the practicum (Flores 2011; Vieira et al. 2013; Flores, Vieira, and Ferreira 2014; Flores 2014). Thus, there is a need for teacher educators to develop a scholarship of teacher education in order to examine the relevance, adequacy and feasibility of approaches to teacher development, to confront and negotiate understandings and epistemological beliefs, and to build practices that improve the quality of their practice, (Flores et al. 2016). This raises questions related to the role of cooperating teachers and university suprvisors who need to position themselves in a inquiry stance.

In my view, the development of a more consistent research-based programme would be better achieved within the context of an Integrated master's degree for teaching (i.e. a 5-year degree). This would make it possible for the development of professional knowledge in its various components, as it would integrate both subject knowledge 
and educational sciences as well as teaching practice in a more integrated and solid way. The consecutive model, as is currently in place, imposes structural and institutional constraints that make the gradual contact with the practice and the engagement with research in a more combined and integrated way more difficult (especially for teaching in upper and lower secondary education). The integrated master's degree model, apart from enhancing the teaching profession, would create the conditions for the development of the professional identity of the student teacher.

It is, therefore, argued that there is a need to reconsider the teacher education curriculum in order to respond to the increasing uncertainties and complexities of teaching in the $21^{\text {st }}$ century, especially at a time when more pressure and demands are placed upon them in contexts marked by growing accountability and greater multiculturalism, (Ben-Peretz \& Flores, 2018). Teachers will need to use their professional judgement 'rather than being driven solely by research evidence or data' (original emphasis, Nelson and Campbell 2017, 128).

As such, a redefinition of university and school roles with a growing emphasis on strong, coherent and supportive partnerships is clearly at the heart of challenging the binary of theory and practice through the combination of teaching and research, researching teaching and teaching research. It implies, therefore, moving beyond a view of teaching practice as a process of adaptation or of application of theory (Flores 2016), one in which student teachers and teachers are not only consumers but also producers of their professional knowledge. For this to happen, besides the research dimension of teaching, it is crucial to include and develop the ethical, social, cultural and political elements in order to promote ITE (and teaching) as a space of transformation. Teaching practice and research become then two crucial elements which also need long term commitment requiring strong and more consistent collaboration between schools and universities.

\section{Acknowledgments}

The author would like to thank her colleague Flávia Vieira for her comments on an earlier draft of this paper.

\section{Disclosure statement}

No potential conflict of interest was reported by the author.

\section{Funding}

The work upon which this paper was based was funded by Fundos Nacionais through FCT (Fundação para a Ciência e a Tecnologia) and co-funded by Fundo Europeu de Desenvolvimento Regional (FEDER) through COMPETE 2020 - Programa Operacional Competitividade e Internacionalização (POCI) at the CIEC (Research Centre on Child Studies) (Reference POCI-01-0145-FEDER-007562).

\section{ORCID}




\section{References}

Afdal, H. W., and K. Spernes. 2018. "Designing and Redesigning Research-Based Teacher Education." Teaching and Teacher Education 74: 215-228. doi:10.1016/j.tate.2018.05.011.

Ben-Peretz, M., and M. A. Flores. 2018. "Tensions and Paradoxes in Teaching: Implications for Teacher Education." European Journal of Teacher Education 41 (2): 202-213.

BERA-RSA. 2014. Research and the Teaching Profession: Building the Capacity for a Self-Improving Education System. Final report of the BERA-RSA inquiry into the role of research in teacher education, London: BERA.ISBN: 978-0-946671-37-3.

Bologna Declaration (1999) http://www.ehea.info/cid100210/ministerial-conference-bologna-1999. html

Braedley, S. 2016. "Research on Fire: Lessons Learned in Knowledge Mobilisation." Technology Innovation Management Review 6 (9): 53-58. doi:10.22215/timreview/1020.

Cain, T. 2015a. "Teachers' Engagement with Published Research: Addressing the Knowledge Problem." The Curriculum Journal 26 (3): 488-509. doi:10.1080/09585176.2015.1020820.

Cain, T. 2015b. "Teachers' Engagement with Research Texts: Beyond Instrumental, Conceptual or Strategic Use." Journal of Education for Teaching 41 (5): 478-492. doi:10.1080/02607476.2015.1105536.

Cain, T. 2016. "Research Utilisation and The Struggle for The Teacher's Soul: a Narrative Review." European Journal of Teacher Education 39 (5): 616-629.

Cain, T., C. Wieser, and K. Livingston. 2016. "Editorial. Mobilising Research Knowledge for Teaching and Teacher Education." European Journal of Teacher Education 39 (5): 529-533. doi:10.1080/ 02619768.2016.1256086.

Conway, P., R. Murphy, A. Rath, and K. Hall. 2009. Learning to Teach and Its Implications for the Continuum of Teacher Education: A Nine-Country Cross-National Study. Report Commissioned by the Teaching Council, University College, Cork, Ireland.

Cooper, A., D. A. Klinger, and P. McAdie. 2017. "What Do Teachers Need? an Exploration of Evidence-Informed Practice for Classroom Assessment in Ontario." Educational Research 59 (2): 190-208. doi:10.1080/00131881.2017.1310392.

Darling-Hammond, L. 2017. "Teacher Education around the World: What Can We Learn from International Practice?" European Journal of Teacher Education 40 (3): 291-309. doi:10.1080/ 02619768.2017.1315399.

Dimmock, C. 2016. "Conceptualising the Research-Practice-Professional Development Nexus: Mobilising Schools as 'Research Engaged' Professional Development Learning Communities." Professional Development in Education 42 (1): 36-53. doi:10.1080/19415257.2014.963884.

Dover, A. G. 2013. "Getting "Up to Code": Preparing for and Confronting Challenges When Teaching for Social Justice in Standards-based Classrooms." Action in Teacher Education 35 (2): 89-102.

Flores, M. A. 2011. "Curriculum of Initial Teacher Education in Portugal: New Contexts, Old Problems." Journal of Education for Teaching 37 (4): 461-470. doi:10.1080/02607476.2011.611015.

Flores, M. A., F. Vieira, and F. I. Ferreira. 2014. "Formação Inicial De Professores Em Portugal: Problemas, Desafios E O Lugar Da Prática Nos Mestrados Em Ensino pós-Bolonha. (Initial Teacher Training in Portugal: Problems, Challenges and the Place of Practice in Master's Degrees in post-Bologna Teaching)." In A Formação Inicial De Professores: Olhares E Perspectivas Nacionais E Internacionais (Initial Teacher Education: National and International Perspectives and Perspectives, edited by M. C. Borges and O. F. Aquino, 61-96. Uberlândia: EDUFU. ISBN: 978-85-7078-373-1.

Flores, M. A. 2014. "Teacher Learning in the Workplace in Pre-Service Teacher Education in Portugal: Potential and Limits from a Pre-Service Teacher Perspective." In Workplace Learning in Teacher Education. International Practice and Policy, edited by O. McNamara, J. Murray, and M. Jones, 243-260). Dordrecht: Springer.

Flores, M. A., F. Vieira, J. L. Silva, and J. Almeida. 2016. "Integrating Research into the Practicum: Inquiring into Inquiry-Based Professional Development in post-Bologna Initial Teacher Education in Portugal." In Redefining Teacher Education for the Post-2015 Era: Global 
Challenges and Best Practice, edited by M. A. Flores and T. Al-Barwani, 109-124. New York: Nova Science Publisher.

Flores, M. A. 2016. "Teacher Education Curriculum." In International Handbook of Teacher Education, edited by J. Loughran and M. L. Hamilton, 187-230. Dordrecht: Springer Press.

Flores, M. A. 2017. "Editorial. Practice, Theory and Research in Initial Teacher Education." European Journal of Teacher Education 40 (3): 287-290. doi:10.1080/02619768.2017.1331518.

Hökkä, P., and A. Eteläpelto. 2014. "Seeking New Perspectives on the Development of Teacher Education: A Study of the Finnish Context." Journal of Teacher Education 65 (1): 39-52. doi:10.1177/0022487113504220.

Ion, G., and R. lucu. 2016. "The Impact of Postgraduate Studies on the Teachers' Practice." European Journal of Teacher Education 39 (5): 602-615. doi:10.1080/02619768.2016.1253674.

Jones, S. L., R. Procter, and S. Younie. 2015. "Participatory Knowledge Mobilisation: An Emerging Model for International Translational Research in Education." Journal of Education for Teaching, 41 (5): 555-573. doi:10.1080/02607476.2015.1105540.

Jyrhama, R., H. Kynaslahti, L. Krokfors, R. Byman, K. Maaranen, A. Toom, and P. Kansanen. 2008. "The Appreciation and Realization of Research-Based Teacher Education: Finnish Students' Experiences of Teacher Education." European Journal of Teacher Education 31 (1): 1-16. doi:10.1080/02619760701844993.

Kincheloe, J. L. (2003). Teachers as researchers: Qualitative inquiry as a path to empowerment, 2nd ed. London \& New York: Routledge Falmer.

Lapostolle, G., and T. Chevaillier. 2011. "Teacher Training in France in the Early 2000s." Journal of Education for Teaching 37 (4): 451-459. doi:10.1080/02607476.2011.611014.

Levin, B. 2013. "To Know Is Not Enough: Research Knowledge and Its Use." Review of Education 1 (1): 2-31. doi:10.1002/rev3.3001.

Marcondes, M. I., V. F. A. Leite, and R. K. Ramos. 2017. "Theory, Practice and Research in Initial Teacher Education in Brazil: Challenges and Alternatives." European Journal of Teacher Education 40 (4): 326-341. doi:10.1080/02619768.2017.1320389.

Matheson, K., and C. M. Edwards. 2016. "Perspectives on Knowledge Mobilisation: An Introduction to the Special Issue." Technology Innovation Management Review 6 (9): 4-8. doi:10.22215/timreview/1014.

Moreira, M. A., and F. Vieira. 2012. "Preservice Teacher Education in Portugal. The Transformative Power of Local Reform." In Globalism and Power. Iberian Education and Curriculum Policies, edited by J. M. Paraskeva and J. Torres, 94-105. New York: Peter Lang.

Nelson, J., and C. Campbell. 2017. "Evidence-Informed Practice in Education: Meanings and Applications." Educational Research 59 (2): 127-135. doi:10.1080/00131881.2017.1314115.

Niemi, H., and A. Nevgi. 2014. "Research Studies and Active Learning Promoting Professional Competences in Finnish Teacher Education." Teaching and Teacher Education 43: 131-142. doi:10.1016/j.tate.2014.07.006.

Ostinelli, G. 2016. "The Many Forms of Research-Informed Practice: A Framework for Mapping Diversity." European Journal of Teacher Education 39 (5): 534-549. doi:10.1080/ 02619768.2016 .1252913$.

Pillen, M., D. Beijaard, and P. Brok. 2013. “Tensions in Beginning Teachers' Professional Identity Development, Accompanying Feelings and Coping Strategies." European Journal of Teacher Education 36 (3): 240-260.

Qvortrup, L. 2016. "Capacity Building: Data and Research-Informed Development of Schools and Teaching Practices in Denmark and Norway." European Journal of Teacher Education 39 (5): 564-576. doi:10.1080/02619768.2016.1253675.

Rey, O., and M. Gaussel. 2016. "The Conditions for the Successful Use of Research Results by Teachers: Reflections on Some Innovations in France." European Journal of Teacher Education 39 (5): 557-587. doi:10.1080/02619768.2016.1260117.

Sachs, J. (2009). Aprender para melhorar ou melhorar a aprendizagem: O dilema do desenvolvimento profissional contínuo dos professores [Learning to improve or improving learning? Teachers' continuing professional development] In: (orgs.) M. Assunção Flores \& A. M. Veiga Simão. Aprendizagem e desenvolvimento profissional de Professores: Contextos e Perspectivas 
[Learning and professional development of teachers: Contexts and perspectives]. (pp 99-118). Mangualde: Edições Pedago.

Snoek, M., J. Bekebrede, F. Hanna, T. Creton, and H. Edzes. 2017. "The Contribution of Graduation Research to School Development: Graduation Research as a Boundary Practice." European Journal of Teacher Education 40 (3): 361-378. doi:10.1080/02619768.2017.1315400.

Valeeva, R. A., and I. R. Gafurov. 2017. "Initial Teacher Education in Russia: Connecting Theory, Practice and Research." European Journal of Teacher Education 40 (3): 324-360. doi:10.1080/ 02619768.2017.1326480.

Van der Walt, M. 2006. "Knowledge Management and Scientific Knowledge Generation." Knowledge Management Research \& Practice 4: 319-330. doi:10.1057/palgrave.kmrp.8500115.

Van Nuland, S. 2011. "Teacher Education in Canada." Journal of Education for Teaching 37 (4): 409-421. doi:10.1080/02607476.2011.611222.

Vieira, F., J. L. Silva, T. Vilaça, C. Parente, F. Vieira, M. J. Almeida, I. Pereira, et al. 2013. “O Papel Da Investigação Na Prática Pedagógica Dos Mestrados Em Ensino. (The Role of Research in the Pedagogical Practice of Masters in Teaching)." In Atas Do XII Congresso Internacional GalegoPortuguês De Psicopedagogia, edited by B. Silva, L. Almeida, A. Barca, M. Peralbo, A. Franco and R. Monginho, 2641-2655. Braga: Universidade do Minho.

Vieira, F. 2014. Synthesis of Data from Survey on Practicum Problems. Internal Document. Braga: University of Minho.

Vieira, F. 2016. "Investigação Pedagógica Na Formação Inicial De Professores: Uma Estratégia Necessária E Controversa, (Pedagogical Research in the Initial Teacher Training: A Necessary and Controversial Strategy)." Revista Estreiadiálogos, (Private Policy) 1 (1): 21-39.

Vieira, F. 2017. “Entre a Reprodução E a Transformação - A Investigação Como Prática Pedagógica Na Formação De Professores (Between Reproduction and Transformation - Research as a Pedagogical Practice in Teacher Training)." In Desafios Curriculares E Pedagógicos Na Formação De Professores, $2^{a}$ Edição Revista E Aumentada (Curricular and Pedagogical Challenges in Teacher Training, 2nd Revised and Increased Edition), edited by M. A. Flores, M. A. Moreira, L. Oliveira, M. A. Flores, M. A. Moreira, and E. L. Oliveira, 141-152. Santo Tirso: De Facto Editores.

Vieira, F., M. A. Flores, J. L. Silva, and J. Almeida. forthcoming. "Understanding and Enhancing Change in post-Bologna Pre-Service Teacher Education: Lessons from Experience and Research in Portugal." In Leading Change in Teacher Education: Lessons from Education Leaders around the Globe, edited by T. Al-Barwani, M. A. Flores, and D. Imig. London: Routledge.

Weiss, C. H. 1979. "The Many Meanings of Research Utilization." Public Administrtaion Review 39 (5): 426-431. doi:10.2307/3109916.

Zeichner, K., and H. G. Conklin. 2008. "Teacher Education Programs as Sites for Teacher Preparation." In Handbook of Research on Teacher Education, edited by M. Cochran-Smith, S. Feiman-Nemser, D. J. McIntyre, and K. E. Demers, 269-289. $3^{\text {rd }}$ ed. New York: Routledge.

Zeichner, K. 2010. "Rethinking the Connections between Campus Courses and Field Experiences in College and University-Based Teacher Education." Educação Revista Do Centro De Educação UFSM 35 (3): 479-501. accessed July, 2018. http://aufop.blogspot.com/2010/07/ken-zeichneruniversityof-washington.html 